\title{
Laccase production by Myrothecium gramineum and its optimization under solid state fermentation using cowpea pod as substrate
}

\author{
V. Daphne Vivienne Gnanasalomi, J. Joel Gnanadoss* \\ Microbial and Environmental Biotechnology Research Unit, Department of Plant Biology and Biotechnology, Loyola College, Chennai, Tamil Nadu, India
}

\begin{tabular}{l}
\hline ARTICLE INFO \\
\hline Article history: \\
Received on: February 13, 2018 \\
Accepted on: September 11, 2018 \\
Available online: January 31, 2019 \\
\hline
\end{tabular}

Key words:

Dried cowpea outer pod,

Laccase,

One-factor-at-a-time,

Solid-state fermentation

\begin{abstract}
The present study highlights the utilization of wastes such as cowpea outer pod generated from agro industries for laccase production using Myrothecium gramineum LCJ177 under solid-state fermentation. Conventional methods were used to optimize the process parameters. The classical one-factor-at-a-time method showed that the optimal starch concentration was $1 \mathrm{~g} / \mathrm{L}$, peptone concentration was $0.5 \mathrm{~g} / \mathrm{L}$, copper sulfate concentration was $0.6 \mathrm{mM}$, and pyrogallol concentration was $0.8 \mathrm{mM}$. Likewise, the suitable physical conditions were an initial $\mathrm{pH}$ of five of the culture medium, the temperature of $30^{\circ} \mathrm{C}$ and moisture content of $60 \%$. Utilization of dried cowpea outer pod as a substrate reduces the pollution levels by converting agro-wastes as useful by-products.
\end{abstract}

\section{INTRODUCTION}

The use of agro-wastes for the production of industrially important products is gaining importance in recent years. The transformation of such wastes to a useful product reduces both the production cost and the pollution caused by it [1]. Agro-wastes are inexpensive and lignocellulosic in nature and rich in sugars, nutrients, and inducers which are essential for the efficient production of enzymes [2,3]. Laccase is an important enzyme responsible for catalyzing the one-electron oxidation of various substrates and reduce molecular oxygen [4]. In the recent years, laccases have gained a lot of importance for its use in various industrial applications such as stabilization of beverages, paper and pulp industry, pharmaceutical industry, decolorization of dyes, and bioremediation of recalcitrant compounds [5,6]. Laccases are present in plants, bacteria, fungi, actinomycetes, and insects; however, the biotechnological important laccases are of fungal origin [7]. Fungi belonging to ascomycetes, Deuteromycetes and basidiomycetes are known to demonstrate laccase activity [8]. Fungal laccases exhibit high redox potential and are hence involved in the degradation of lignin and toxic phenols without the formation of toxic intermediates [4]. The production of laccases has been widely carried out by submerged fermentation, yet this type of fermentation does not imitate the original living condition of the fungi.

*Corresponding Author:

Dr. J. Joel Gnanadoss,

Microbial and Environmental Biotechnology Research Unit,

Department of Plant Biology and Biotechnology,

Loyola College, Chennai - 600 034, Tamil Nadu, India.

Email:joelgna@gmail.com
In submerged fermentation, the synthesis of laccase requires induction by phenolic and aromatic compounds which are costly, unsafe, and toxic [9]. Therefore, solid-state fermentation (SSF) which is more advantageous over submerged fermentation is being used. The advantages of SSF include low water requirement and wastewater output, easy product recovery, and high product titers. SSF is emerging as a cost-effective method for the production of bio-products using agro-wastes [10]. The laccase production under SSF requires optimization of process parameters to enhance the production [11]. The conventional one factor at a time strategy is the most commonly used method of optimization $[12,13]$.

Various agro-wastes are used for the production of laccases; however, there is no information on the use of dried cowpea outer pod as a substrate for laccase production under SSF. Cowpea is a leguminous crop consisting of proteins (24\%), carbohydrates (62\%), and various vitamins which are known to induce the production of enzymes. Thus, it is interesting to adopt new substrates for the production of laccases using cost-effective methods due to its immense potential in various applications. Therefore, the present study represents the feasibility of cowpea outer pod as a substrate for the production of laccases by Myrothecium gramineum. This is the first report on laccase production using dried cowpea pod as a substrate to the best of our knowledge.

\section{MATERIAL AND METHODS}

\subsection{Substrate Used}

Cowpea pods used in this study were purchased from the local market in Chennai. The pods were sun-dried and then beaten to remove the seeds. The remaining outer pod was used for the study. 


\subsection{Microorganism}

M. gramineum LCJ177 used for this study was collected from Loyola College, Chennai [14] and maintained on potato dextrose agar plates at $4^{\circ} \mathrm{C}$ and sub-cultured periodically.

\subsection{Culture Conditions for Laccase Production}

The culture media used for the laccase production by M. gramineum LCJ177 were prepared according to the method described earlier [15].

The experiments under SSF were carried out in stoppered glass bottles $(200 \mathrm{~mL})$ containing $5 \mathrm{~g}$ of the substrate. The substrate was moistened with $50 \mathrm{~mL}$ of the culture medium for $5 \mathrm{~h}$ after which the excess medium was drained, and the final moisture content of the substrates was maintained at $50 \%$. The bottles containing the substrates moistened with the suitable medium were autoclaved at $121^{\circ} \mathrm{C}$ for $30 \mathrm{~min}$, cooled and inoculated with two fungal mycelial discs $(4 \mathrm{~mm})$ which were 5 days old. The flasks were incubated at room temperature under stationary condition.

The effect of incubation time on the growth and laccase production by M. gramineum LCJ177 under SSF was studied. The sterilized bottles containing the substrates were inoculated with two fungal mycelial discs $(4 \mathrm{~mm})$ and incubated for 30 days. The laccase activity was estimated at a 5 days interval. At the end of every incubation period, the crude filtrate was extracted as described before and the laccase activity was estimated. Simultaneously, the fresh weight was estimated at an interval of 5 days. The initial weight of the bottles containing the substrates was weighed before inoculation. After the respective incubation period, the bottles containing the fermented substrates were weighed again to determine the final weight. The difference between the final and initial weight showed the fresh weight of the fungi.

\subsection{Enzyme Extraction}

Extraction of the crude enzyme was done by adding $50 \mathrm{~mL}$ of glycine$\mathrm{NaOH}$ buffer $(100 \mathrm{mM}, \mathrm{pH} 8.6)$ to the fermented substrate and incubated on an orbital shaker (120 rpm) overnight to allow the buffer to extract the crude enzyme. The contents of the bottles were filtered using a muslin cloth to separate the crude enzyme from the solid substrate. The crude filtrate was centrifuged further at 10,000 rpm for $15 \mathrm{~min}$ to remove any suspended substrate particles. The collected supernatant was used for the laccase assay.

\subsection{Laccase Assay}

The laccase activity was measured using guaiacol as the substrate [16]. The reaction mixture consisted of $3 \mathrm{~mL}$ of guaiacol $(10 \mathrm{mM})$ in sodium acetate buffer (100 mM and $\mathrm{pH} 5.0)$, dissolved in $10 \%$ acetone $(\mathrm{v} / \mathrm{v})$ and $1 \mathrm{~mL}$ culture filtrate was added to it, and the mixture was incubated for $15 \mathrm{~min}$. The laccase activity was measured at an absorbance of $470 \mathrm{~nm} .1$ unit (U) of laccase activity was defined as the amount of enzyme that oxidizes $1 \mu \mathrm{mol}$ of guaiacol. The blank contained all the assay components except the active enzyme which was substituted with $1 \mathrm{~mL}$ of the buffer or heat-inactivated culture filtrate.

The calculation is as follows:

Laccase $(\mathrm{U} / \mathrm{mL})=\frac{\left(\begin{array}{l}\Delta \mathrm{A}_{470} \times \text { Total volume } \times \\ \text { Dilution factor } \times 10^{6}\end{array}\right)}{€_{\text {Guaiacol }} \times \text { sample volume }} \times 1000$

$\Delta \mathrm{A}_{470}=$ Rate of reaction, that is, final absorbance-Initial absorbance $\div$ time (min)

Total volume $=$ Final volume of reaction mixture $(\mathrm{mL})$
Sample volume $=$ Volume of enzyme $(\mathrm{mL})$

$€_{\text {Guaiacol }}=$ Molar extinction coefficient of guaiacol (27.75)

\subsection{Optimization Studies}

The optimization process was carried out by the one factor at a time method by varying a single parameter at a time while keeping the other parameters as constant. The optimal concentration of starch (1-5 g/L), peptone (1-5 g/L), copper sulfate $(0-1 \mathrm{mM})$, and pyrogallol $(0-1 \mathrm{mM})$ was studied. The physical factors such as $\mathrm{pH}(4-8)$, temperature $\left(28-36^{\circ} \mathrm{C}\right)$, moisture content $(20-100 \%)$, and inoculum size $(2-10 \mathrm{~g} / \mathrm{kg}$ ) were also evaluated. The crude enzyme was extracted on the day of maximum laccase production and assayed for laccase activity.

\subsection{Statistical Analysis}

The statistical analysis of the data is represented in the tables. The data were statistically analyzed using one-way ANOVA followed by Tukey's multiple comparison test with the statistical significance set at $P<0.05$. The mean and standard deviation (SD) was calculated and expressed as mean $\pm \mathrm{SD}$ of the triplicates. The statistical analysis was performed using SPSS 11.5 software.

\section{RESULTS AND DISCUSSION}

\subsection{Effect of Incubation Time on Laccase Production}

The nature and nutrient composition of the substrates influences the incubation time required for colonizing the substrate and influences the enzyme production depending on the genetic difference found among the different strains $[17,18]$. The effect of incubation time on the growth and laccase production by Psathyrella candolleana LCJ178 was evaluated. The laccase production was monitored for 30 days. In P. candolleana LCJ178, the maximum laccase production of $8.64 \mathrm{U} / \mathrm{g}$ ds was observed on the $15^{\text {th }}$ day of incubation [Figure 1]. Increase in the incubation time over 15 days decreased the laccase production by P. candolleana LCJ178. Different patterns in the production of laccase by Trametes versicolor cultivated on Eucalyptus grandis wood chips was observed with reference to incubation time [19]. The maximum laccase production by $T$. versicolor was obtained after 60 days of incubation. It was also reported that high levels of laccase were produced by Pleurotus ostreatus and Datronia sp. KAP10039 after 8 days of incubation when wheat straw was used as the substrate $[20,21]$.

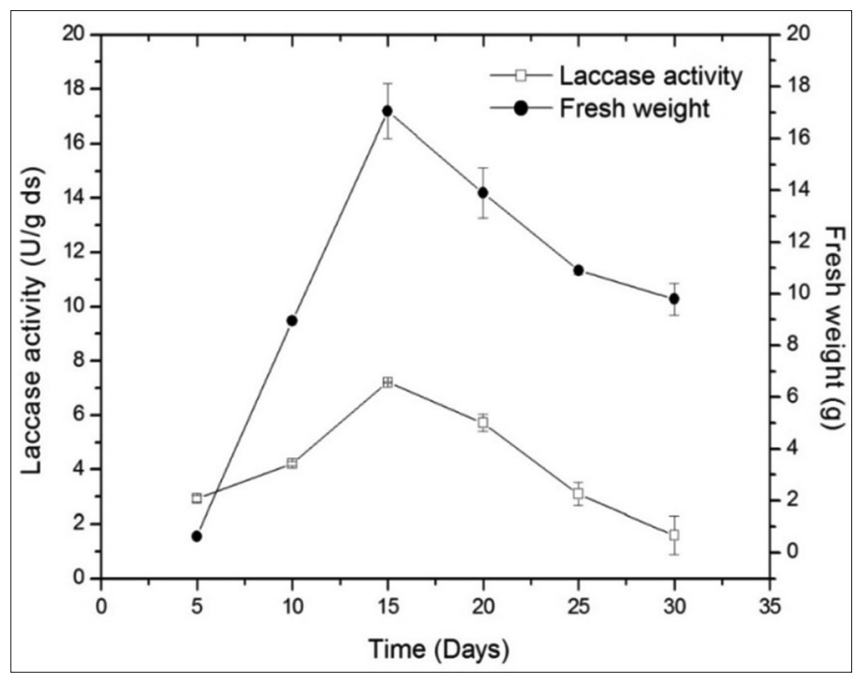

Figure 1: Growth and laccase production by Myrothecium gramineum LCJ177 using dried cowpea outer pod as a substrate 


\subsection{Effect of Carbon Source Concentration}

The concentration of carbon is a critical factor for regulating laccase production [22]. Among the different concentrations of starch tested, addition of $1.0 \mathrm{~g} / \mathrm{L}$ of starch resulted in maximum laccase production of $7.84 \mathrm{U} / \mathrm{g} \mathrm{ds}$, and it was significant $(P<0.05)$. Substantial laccase production was also observed by the addition of $0.5 \mathrm{~g} / \mathrm{L}$ of starch with a laccase activity of $5.88 \mathrm{U} / \mathrm{g}$ ds [Figure 2]. Addition of easily available carbon sources to the substrates increases the growth and enzyme production by the fungi [23]. The carbon supplement when used along with the substrates induces the genes involved with the metabolism of alternative carbon sources and consequently enhances the laccase production [24].

\subsection{Effect of Nitrogen Source Concentration}

The laccase synthesis is regulated by the nitrogen concentration in the cultivation medium [25]. Addition of nitrogen sources to the solid substrates had a considerable effect on the growth of the fungi and its enzyme production [26]. In the present investigation, addition of $0.5 \mathrm{~g} / \mathrm{L}$ of peptone enhanced the laccase production $(8.17 \mathrm{U} / \mathrm{g} \mathrm{ds})$ [Figure 3]. Substantial laccase activity of $6.73 \mathrm{U} / \mathrm{g}$ ds was also observed by adding $1.0 \mathrm{~g} / \mathrm{L}$ of peptone to dried cowpea outer pod. It has also been reported that the presence of an organic nitrogen source along with a lignocellulosic substrate augmented the production of laccases due to the presence of extra nutrients [27].

\subsection{Effect of Inducers on Laccase Production}

\subsubsection{Effect of copper sulfate concentration}

Copper plays a key role as a metal activator and enhances laccase production to a considerable quantity $[28,29]$. In the present study, addition of copper sulfate at a concentration of $0.6 \mathrm{mM}$ augmented the laccase production by M. gramineum LCJ177 with a laccase activity of $14.50 \mathrm{U} / \mathrm{g}$ ds [Table 1]. The results were also significant at 5\% level. In the same way, the addition of copper sulfate at different concentration stimulated laccase production by Pleurotus eryngii and Tramates pubesens under SSF. However, when the concentration of copper was increased beyond the optimal concentration, a significant decrease in the growth and laccase production was observed which is attributed to the toxic effect of copper at high concentrations [30].

\subsubsection{Effect of pyrogallol concentration}

Various aromatic inducers and phenolic compounds related to lignin, lignin derivates, and lignin precursors have been known to stimulate and enhance laccase production [18,29,31] The type of inducers added, their chemical nature, the quantity added and the time of addition of these inducers influence laccase production, and this varies with different species. In this study, addition of pyrogallol at a concentration of $0.8 \mathrm{mM}$ augmented the laccase production ( $11.66 \mathrm{U} / \mathrm{g} \mathrm{ds})$. Considerable laccase activity of $10.21 \mathrm{U} / \mathrm{g}$ ds was observed by adding $0.6 \mathrm{mM}$ of pyrogallol as shown in Table 1. The statistical analysis showed that there was no significant difference in the laccase production by adding $0.2-1.0 \mathrm{mM}$ of pyrogallol when dried cowpea outer pod was used as the substrate.

\subsection{Effect of Different Physical Factors on Laccase Production}

\subsubsection{Effect of initial pH of the medium}

The physical parameters such as $\mathrm{pH}$ and temperature have been found to play a significant role in enzyme production [32]. The $\mathrm{pH}$ of the SSF substrate has a significant influence on laccase production as the fungi are sensitive to the variation in $\mathrm{pH}$ [33]. The optimum $\mathrm{pH}$ range for laccase production was usually found to be in the range of 4-6 for most fungi [34]. The present study showed that maximum

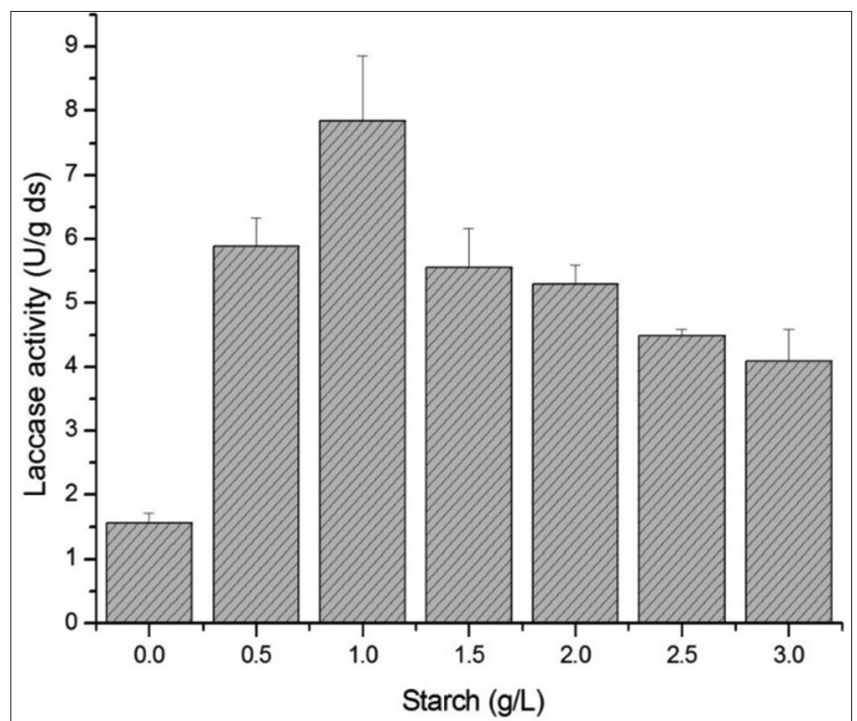

Figurer 2: Effect of various concentrations of starch on the laccase production by Myrothecium gramineum LCJ177 on the $15^{\text {th }}$ day (peak day)

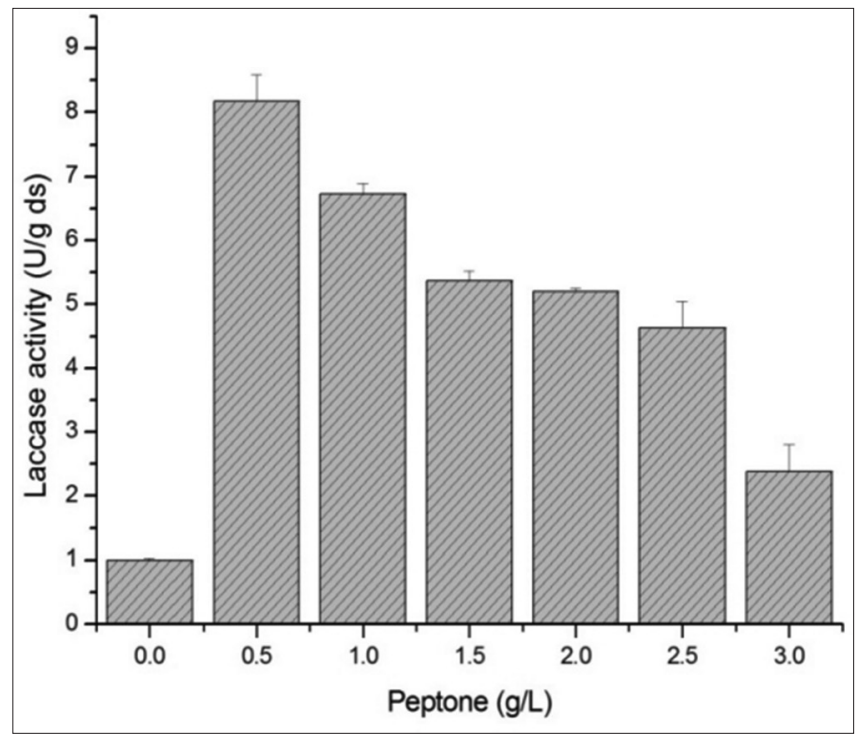

Figure 3: Effect of various concentrations of peptone on the laccase production by Myrothecium gramineum LCJ177 on the $15^{\text {th }}$ day (peak day)

laccase by M. gramineum LCJ177 was observed at an initial $\mathrm{pH}$ of $5(18.41 \mathrm{U} / \mathrm{g}$ ds $)$. The statistical analysis of the data showed that $\mathrm{pH} 5$ was significant $(P<0.05)$ for the laccase production by $M$. gramineum LCJ177 compared with the other pH levels as shown in Table 2. A further increase in $\mathrm{pH}$ above the optimum $\mathrm{pH}$ caused a decrease in laccase production. This is because the change in $\mathrm{pH}$ alters the threedimensional structure of the enzyme [35].

\subsubsection{Effect of temperature}

Temperature plays an important role in the SSF medium and its control over the SSF process is crucial $[18,33,36]$. During the fermentation process, an increase in the temperature of the fermenting mass occurs due to respiration [37]. The optimum temperature for laccase production ranges between 25 and $37^{\circ} \mathrm{C}$ [38]. In the present study, a temperature of $30^{\circ} \mathrm{C}$ was suitable for augmenting the laccase production (16.51 U/g ds) by M. gramineum LCJ177 [Table 2]. A decrease in 
Table 1: Effect of various concentrations of inducers (copper sulfate and pyrogallol) on the laccase production by Myrothecium gramineum LCJ177 on the $15^{\text {th }}$ day (peak day)

\begin{tabular}{lc} 
Copper sulfate $(\mathbf{m M})$ & \begin{tabular}{c} 
Laccase activity $(\mathbf{U}$ gds $)$ \\
\cline { 2 - 2 }
\end{tabular} \\
\hline 0.0 & $(\boldsymbol{P}=\mathbf{0 . 0 0 0 * *})$ \\
0.2 & $9.29 \pm 0.47$ \\
0.4 & $11.27 \pm 0.35^{\mathrm{b}}$ \\
0.6 & $12.35 \pm 0.0^{\mathrm{b}}$ \\
0.8 & $14.50 \pm 0.10^{\mathrm{c}}$ \\
1.0 & $11.16 \pm 0.17^{\mathrm{b}}$ \\
Pyrogallol $(\mathbf{m M})$ & $4.22 \pm 0.36^{\mathrm{a}}$ \\
0.0 & $(\boldsymbol{P}=\mathbf{0 . 0 0 0 * *})$ \\
0.2 & $7.96 \pm 0.65$ \\
0.4 & $9.83 \pm 0.84^{\mathrm{a}}$ \\
0.6 & $10.02 \pm 1.1^{\mathrm{a}}$ \\
0.8 & $10.21 \pm 0.20^{\mathrm{a}}$ \\
1.0 & $11.66 \pm 0.53^{\mathrm{a}}$ \\
\hline
\end{tabular}

Table 2: Effect of various physical factors on the laccase production by Myrothecium gramineum LCJ177 on the $15^{\text {th }}$ day (peak day)

\begin{tabular}{|c|c|}
\hline \multirow[t]{2}{*}{ pH } & Laccase activity (U/g ds) \\
\hline & $(P=0.002 * *)$ \\
\hline 4 & $11.18 \pm 0.24^{\mathrm{a}}$ \\
\hline 5 & $18.41 \pm 0.07^{\mathrm{c}}$ \\
\hline 6 & $17.62 \pm 0.08^{\mathrm{bc}}$ \\
\hline 7 & $16.80 \pm 0.01^{\mathrm{bc}}$ \\
\hline 8 & $14.95 \pm 1.31^{\mathrm{b}}$ \\
\hline Temperature $\left({ }^{\circ} \mathrm{C}\right)$ & $(P=0.003 * *)$ \\
\hline 26 & $10.20 \pm 0.10^{\mathrm{b}}$ \\
\hline 28 & $12.38 \pm 0.24^{\mathrm{c}}$ \\
\hline 30 & $16.51 \pm 0.70^{\mathrm{d}}$ \\
\hline 32 & $9.80 \pm 0.12^{\mathrm{b}}$ \\
\hline 34 & $8.21 \pm 0.58^{b}$ \\
\hline 36 & $3.25 \pm 0.34^{\mathrm{a}}$ \\
\hline Inoculum size (g/kg) & $(P=0.003 * *)$ \\
\hline 2 & $12.91 \pm 1.51^{\mathrm{a}}$ \\
\hline 4 & $17.56 \pm 1.30^{\mathrm{a}}$ \\
\hline 6 & $14.96 \pm 1.28^{\mathrm{a}}$ \\
\hline 8 & $10.33 \pm 1.62^{\mathrm{a}}$ \\
\hline 10 & $9.88 \pm 1.53^{\mathrm{a}}$ \\
\hline Moisture content (\%) & $(P=0.000 * *)$ \\
\hline 20 & $2.63 \pm 0.26^{\mathrm{a}}$ \\
\hline $\mathrm{s} 40$ & $5.88 \pm 1.17^{\mathrm{b}}$ \\
\hline 60 & $7.78 \pm 0.55^{\mathrm{c}}$ \\
\hline 80 & $4.28 \pm 0.08^{\mathrm{b}}$ \\
\hline 100 & $3.00 \pm 1.0^{\mathrm{a}}$ \\
\hline
\end{tabular}

the laccase yield was observed when the incubation temperature was higher or lower than the optimal incubation temperature.

\subsubsection{Effect of inoculum size}

The inoculum size also plays an important role in SSF. A low inoculum level is not sufficient to initiate growth, and a high inoculum level causes competitive inhibition [39]. An initial inoculum size of $4 \mathrm{~g} / \mathrm{kg}$ favored maximum laccase production $(17.56 \mathrm{U} / \mathrm{g} \mathrm{ds})$. Substantial laccase production was also observed by adding $2 \mathrm{~g} / \mathrm{kg}$ of inoculum with a laccase activity of $12.91 \mathrm{U} / \mathrm{g}$ ds. A further increase in inoculum size decreases laccase production due to the fast depletion of nutrients leading to decreased metabolic activity [18].

\subsubsection{Effect of initial moisture content}

Moisture content is an important parameter which controls the growth, enzyme secretion, stability, and swelling of the substrate under SSF. The water needed for the fungal growth and the final end product depends on the water holding capability and moisture levels in the SSF process. Therefore, the moisture level should be in the appropriate range [40]. In this study, different moisture levels were studied. The maximum laccase production was obtained at a moisture content of $60 \%$. Under this condition, a laccase activity of $7.78 \mathrm{U} / \mathrm{g}$ ds was obtained [Table 2]. When the moisture levels were increased, further the laccase production decreased. Increase in moisture levels $>80 \%$ is not permissible since free-flowing water is observed. High and low moisture levels are inhibitory to laccase production due to the poor accessibility of nutrients and limited aeration [41].

\section{CONCLUSION}

The study shows that cheap agro-materials such as dried cowpea outer pod which was discarded as waste previously could be utilized as a substrate for the production of laccases. The study also highlights the importance of the conventional method of optimization of laccase production which would provide baseline information for further optimization by statistical tools. The results also demonstrate the importance of nutritional and physical parameters on enzyme production.

\section{ACKNOWLEDGMENTS}

The authors are thankful to the Management, Loyola College, Chennai, Tamil Nadu, India, for providing necessary facilities and encouragement.

\section{REFERENCES}

1. Hailei W, Ping L, Yuhua Y, Yufeng L. Overproduction of laccase from a newly isolated Ganoderma lucidum using the municipal food waste as main carbon and nitrogen supplement. Bioprocess Biosyst Eng 2015;38:957-66.

2. Couto RS. Exploitation of biological wastes for the production of value-added products under solid-state fermentation conditions. Biotechnol J 2008;3:859-70.

3. Iandolo D, Piscitelli A, Sannia G, Faraco V. Enzyme production by solid substrate fermentation of Pleurotus ostreatus and Trametes versicolor on tomato pomace. Appl Biochem Biotechnol 2010;163:40-51.

4. Nyanhongo GS, Gomes J, Gubitz G, Zvauya R, Read JS, Steiner W. Production of laccase by a newly isolated strain of Trametes modesta. Bioresour Technol 2002;84:259-63.

5. Bhamare HM, Jadhav HP, Sayyed RZ. Statistical optimization for enhanced production of extracellular laccase from Aspergillus sp. $\mathrm{HB}_{-}$ RZ4 isolated from bark scrapping. Environ Sustain 2018;1:159-66.

6. Pezzella C, Guarino L, Piscitelli A. How to enjoy laccases. Cell Mol Life Sci 2015;72:923-40. 
7. Kalmis E, Azbar N, Yildiz H, Kalyoncu F. Feasibility of using olive mill effluent (OME) as a wetting agent during the cultivation of oyster mushroom, Pleurotus ostreatus, on wheat straw. Bioresour Technol 2008;99:164-9.

8. Kiiskinen LL, Rättö M, Kruus K. Screening for novel laccaseproducing microbes. J Appl Microbiol 2004;97:640-6.

9. Aydinoğlu T, Sargin S. Production of laccase from Trametes versicolor by solid-state fermentation using olive leaves as a phenolic substrate. Bioprocess Biosyst Eng 2013;36:215-22.

10. Pandey A, Soccol CR, Nigam P, Soccol VT, Vandenberghe LP, Mohan R. Biotechnological potential of agro-industrial residues. II: Cassava bagasse. Bioresour Technol 2007;4:81-7.

11. Kumar S, Mishra A. Optimization of laccase production from WRF-1 on groundnut shell, cyanobacterial biomass: By application of box-behnken experimental design. J Microbiol Biotechnol Res 2011;1:33-53.

12. Prasad KK, Mohan SV, Rao RS, Pati BR, Sarma P. Laccase production by Pleurotus ostreatus 1804: Optimization of submerged culture conditions by taguchi DOE methodology. Biochem Eng J 2005;24:17-26.

13. Levin L, Herrmann C, Papinutti VL. Optimization of lignocellulolytic enzyme production by the white-rot fungus Trametes trogii in solidstate fermentation using response surface methodology. Biochem Eng J 2008;39:207-14.

14. Gnanasalomi VD, Gnanadoss JJ. Molecular characterization and phylogenetic analysis of laccase producing fungal isolates with dye decolourizing potential. Res Biotechnol 2013;4:1-8.

15. Novotný C, Rawal B, Bhatt M, Patel M, Sasek V, Molitoris HP, et al. Capacity of Irpex lacteus and Pleurotus ostreatus for decolorization of chemically different dyes. J Biotechnol 2001;89:113-22.

16. Collins PJ, Dobson A. Regulation of laccase gene transcription in Trametes versicolor. Appl Environ Microbiol 1997;63:3444-50.

17. Giardina P, Palmieri G, Fontanella B, Rivieccio V, Sannia G. Manganese peroxidase isoenzymes produced by Pleurotus ostreatus grown on wood sawdust. Arch Biochem Biophys 2000;376:171-9.

18. Patel H, Gupte A, Gupte S. Effect of different culture conditions and inducers on production of laccase by a basidiomycete fungal isolate Pleurotus ostreatus HP-1 under solid state fermentation. Bioresources 2009;4:268-84.

19. Machuca A, Ferraz A. Hydrolytic and oxidative enzymes produced by white and brown-rot fungi during Eucalyptus grandis decay in solid state medium. Enzyme Microbial Technol 2001;29:386-91.

20. Gupte A, Gupte S, Patel H. Ligninolytic enzyme production under solid state fermentation by white rot fungi. J Sci Ind Res 2007;66:611-4.

21. Vaithanomsat P, Apiwatanapiwat W, Petchoy O, Chedchant J. Production of ligninolytic enzymes by white-rot fungus Datronia sp. KAPI0039 and their application for reactive dye removal. Int J Chem Eng 2010;2010:1-6.

22. Songulashvili G, Elisashvili V, Wasser SP, Nevo E, Hadar Y. Basidiomycetes laccase and manganese peroxidase activity in submerged fermentation of food industry wastes. Enzyme Microbial Technol 2007;41:57-61.

23. Selvam K, Swaminathan K, Rasappan K, Rajendran R, Pattabi S. Decolourization and dechlorination of a pulp and paper industry effluent by Thelephora sp. Ecol Environ Conserv 2006;12:223-6.

24. Stajic M, Persky L, Friesem D, Hadar Y, Wasser SP, Nevo E, et al. Effect of different carbon and nitrogen sources on laccase and peroxidases production by selected Pleurotus species. Enzyme Microbial Technol 2006;38:65-73.
25. Galhaup C, Goller S, Peterbauer CK, Strauss J, Haltrich D. Characterization of the major laccase isoenzyme from Trametes pubescens and regulation of its synthesis by metal ions. Microbiology 2002;148:2159-69.

26. Mishra A, Kumar S. Cyanobacterial biomass as N-supplement to agro-waste for hyper-production of laccase from Pleurotus ostreatus in solid state fermentation. Process Biochem 2007;42:681-5.

27. Kapich AN, Prior BA, Botha A, Galkin S, Lundell T, Hatakka A. Effect of lignocelluloses-containing substrates on production of ligninolytic peroxidases in submerged cultures of Phanerochaete chrysosporium ME-446. Enzyme Microbial Technol 2004;34:187-95.

28. Leonowicz A, Cho NS, Luterek J, Wilkolazka A, WojtasWasilewska M, Matuszewska A, et al. Fungal laccase: Properties and activity on lignin. J Basic Microbiol 2001;41:185-227.

29. Ikehata K, Buchanan ID, Smith DW. Recent developments in the production of extracellular fungal peroxidases and laccases for waste treatment. J Environ Eng Sci 2004;3:1-19.

30. Galhaup C, Goller S, Peterbauer CK, Strauss J, Haltrich D. Characterization of the major laccase isoenzyme from Trametes pubescens and regulation of its synthesis by metal ions. Microbiology 2002;149:2159-69.

31. de Souza CG, Tychanowicz GK, de Souza DF, Peralta RM. Production of laccase isoforms by Pleurotus pulmonarius in response to presence of phenolic and aromatic compounds. J Basic Microbiol 2004;44:129-36.

32. Nandal P, Ravella SR, Kuhad RC. Laccase production by Coriolopsis caperata RCK2011: Optimization under solid state fermentation by Taguchi DOE methodology. Sci Rep 2013;3:1-7.

33. Asgher M, Ahmed N, Iqbal HM. Hyperproductivity of extracellular enzymes from indigenous white rot fungi (Phanerochaete Chrysosporium) by utilizing agro-wastes. Bioresources 2011;6:4454-67.

34. Gowthaman MK, Krishna C, Moo-Young M. Fungal solid state fermentation - An overview. Appl Mycol Biotechnol 2001;1:305-52.

35. Shuler ML, Kargi F. Bioprocess Engineering Basic Concept. $2^{\text {nd }}$ ed., New Delhi, India: Prentice-Hall of India Pvt Ltd.; 2000. p. 75-8.

36. Tekere M, Mswaka AY, Zvauya R, Read JS. Growth, dye degradation and ligninolytic activity studies on Zimbabwean white rot fungi. Enzyme Microb Technol 2001;28:420-6.

37. Niladevi KN, Sukumaran RK, Prema P. Utilization of rice straw for laccase production by Streptomyces psammoticus in solid-state fermentation. J Ind Microbiol Biotechnol 2007;34:665-74.

38. Vasudev K, Dhawan S, Kapoor RK, Kuhad RC. Biochemical characterization and molecular evidence of a laccase from the bird's nest fungus Cyathus bulleri. Fungal Genet Biol 2005;42:684-93.

39. Sabu A, Pandey A, Daud MJ, Szakacs G. Tamarind seed powder and palm kernel cake: Two novel agro residues for the production of tannase under solid state fermentation by Aspergillus niger ATCC 16620. Bioresour Technol 2005;96:1223-8.

40. Durand A. Bioreactor designs for solid state fermentation. Biochem Eng J 2003;13:113-25.

41. Bhatti HN, Nawaz S. Production of endoglucanase by Fusarium solani grown in solid-state fermentation. Asian J Chem 2009;21:1943-8.

\footnotetext{
How to cite this article:

Gnanasalomi VDV, Gnanadoss JJ. Laccase production by Myrothecium gramineum and its optimization under solid state fermentation using cowpea pod as substrate. J App Biol Biotech. 2019;7(02):59-63. DOI: $10.7324 / J A B B .2019 .70211$
} 